(2) Open Access Full Text Article

\title{
Caspase Cascade Activation During Apoptotic Cell Death of Human Lung Carcinoma Cells A549 Induced by Marine Sponge Callyspongia aerizusa
}

This article was published in the following Dove Press journal:

Drug Design, Development and Therapy

\author{
Yuni Elsa Hadisaputri $\mathbb{D}^{1,2, *}$ \\ Rheza Andika 1,2,* \\ Iyan Sopyan ${ }^{3}$ \\ Ade Zuhrotun' \\ Rani Maharani ${ }^{2,4}$ \\ Rachmaniar Rachmat ${ }^{5}$ \\ Rizky Abdulah iD ${ }^{6}$ \\ 'Department of Pharmaceutical Biology, \\ Faculty of Pharmacy, Universitas \\ Padjadjaran, Jatinangor, Indonesia; \\ ${ }^{2}$ Division of Biological Activity, Central \\ Laboratory, Universitas Padjadjaran, \\ Jatinangor, Indonesia; ${ }^{3}$ Department of \\ Pharmaceutical and Pharmacy \\ Technology, Faculty of Pharmacy, \\ Universitas Padjadjaran, Jatinangor, \\ Indonesia; ${ }^{4}$ Department of Chemistry, \\ Faculty of Mathematic and Sciences, \\ Universitas Padjadjaran, Jatinangor, \\ Indonesia; ${ }^{5}$ Oceanographic Research \\ Center, Indonesian Institute of Sciences, \\ Jakarta, Indonesia; ${ }^{6}$ Department of \\ Pharmacology and Clinical Pharmacy, \\ Faculty of Pharmacy, Universitas \\ Padjadjaran, Jatinangor, Indonesia \\ *These authors contributed equally to \\ this work
}

Correspondence: Yuni Elsa Hadisaputri Department of Pharmaceutical Biology, Faculty of Pharmacy, Universitas Padjadjaran, Jl. Raya Bandung-Sumedang KM.2I, Jatinangor, West Java, 45363, Indonesia

Tel +62-22-84288888 Ext. 3510

Email yuni.elsa@unpad.ac.id
Introduction: In this study, Callyspongia aerizusa (CA), one of the most popular marine sponges for cancer therapy research, was investigated for its phytochemical compounds and evaluated for its anticancer activity in various cell lines. Since lung cancer is the most frequently diagnosed cancer, a solution from this marine source is a good choice to address the resistance to anticancer agents. Elucidation of the underlying mechanism of cell death elicited by a CA extract in human lung carcinoma cells A549 was undertaken.

Methods: The presence of secondary metabolites in CA methanol extract was revealed by gas chromatography-mass spectrometry (GC-MS) and evaluated on four cancerous cell lines and a non-cancerous cell line using Cell Counting Kit-8. Since the activity of CA extract in A549 cells was then evaluated through clonogenic assay, morphological detection of apoptosis, polymerase chain reaction (PCR) and Western blot assay, were also presented in this study.

Results: GC-MS analysis revealed the presence of two ergosteroids, ergost-22-en -3-one, $(5 \beta, 22 E)$, and ergost-7-en-3-ol, $(35 \beta)$ in the sponge extract that was suggested to suppress $\mathrm{A} 549$ cells $\left(\mathrm{IC}_{50} 9.38 \mu \mathrm{g} / \mathrm{mL}\right.$ ), and another cancerous cell's viability ( $\mathrm{IC}_{50}$ $3.12-10.72 \mu \mathrm{g} / \mathrm{mL}$ ) in $24 \mathrm{~h}$, but not in the non-cancerous cells. Moreover, CA extract was also able to reduce the colony-forming ability of A549 cells, and through A549 cells morphology seems that apoptosis is the underlying mechanism of cell death. Further, the treatment with CA extract induced the up-regulation of caspase-9, caspase-3, and PARP-1, and the down-regulation of BCL-2, in both $m R N A$ and proteins expression level, promoting apoptotic cell death via caspase cascade.

Conclusion: These findings suggest that the compounds in CA extract possess the ability to induce apoptotic cell death in A549 cells and could become a promising candidate for future anticancer therapy.

Keywords: Callyspongia aerizusa, ergosteroids, lung cancer, A549, apoptosis

\section{Introduction}

A lot of effort and investment has been devoted to developing cancer treatments, proven by the number of related studies that had been conducted since the late 19th century; ${ }^{1}$ however, cancer remains a global problem to date. Lung cancer, the most commonly diagnosed cancer, occurs in $12.9 \%$ of total cancer new cases and is related to $19.4 \%$ of total cancer-related deaths. ${ }^{2}$ Moreover, it is expected that the burden of this disease will rise by about $70 \%$ in the next two decades. ${ }^{3}$ Resistance to anticancer drugs had been reported as a serious problem in the field of cancer and causes $90 \%$ of the failures of chemotherapy. ${ }^{4}$ Therefore, research to find novel 
therapeutic agents with a better pharmaco-toxicological profile are still continuing to date.

The marine environment is known as a notable source of novel bioactive natural products with structural and chemical features that are often not found in terrestrial natural products. ${ }^{5,6}$ So far, the majority of marine natural products have been isolated from invertebrates, and Porifera has been reported as the most dominant source. ${ }^{7}$ Marine sponges are known to not develop cancers due to their efficient biotransformation and detoxification systems, which prevent the generation of DNA lesions. ${ }^{8,9}$ It is possible that this might be related to the production of certain metabolites that act as anticancer agents for the organisms. The potential anticancer activities of marine sponge-derived metabolites are reported by multiple cellular and molecular mechanisms, such as cell cycle arrest, ${ }^{10}$ apoptosis, ${ }^{11}$ anti-inflammatory activities ${ }^{12}$ and chemo-sensitization to radiotherapy. ${ }^{13}$ One of the marine sponges that possesses efficacy to treat cancer is Callyspongia aerizusa.

Callyspongia aerizusa (CA) was firstly introduced by Desqueyroux-Faúndez in $1984,{ }^{14}$ however, there are only a few scientific studies that have reported the therapeutic potential of CA. A series of cyclic peptides isolated from CA extract, the Callyaerins, are known to be biologically active at various level of cytotoxicity against several types of cancerous cell lines, such as mouse lymphoma cells (L5178Y), rat pheochromocytoma cells (PC12), and cervical adenocarcinoma cells (HeLa). ${ }^{15}$ However, its potential therapeutic effect on other types of cancer and its molecular mechanism remains unknown.

In the present study, the active compound group in CA extract was phytochemically screened and evaluated on some cancerous (A549, Hep G2, MIA PaCa-2, and TE-8) and non-cancerous (Het-1A) cell lines. The study was then followed by a colony formation inhibition assay of A549 cells. Moreover, the mechanism of cell death elicited by CA extract was morphologically observed, and its possible molecular mechanism on A549 cells was presented in both $m R N A$ and protein expression levels in this study.

\section{Materials and Methods}

\section{Callyspongia aerizusa Collection and Extraction}

The marine sponge, Callyspongia aerizusa (CA), was collected by scuba diving at a depth of $20-30 \mathrm{~m}$ in the Polewali Mandar Sea, West Sulawesi, Indonesia, under the Oceanographic Research Center, Indonesian Institute of
Sciences' research project of Sulawesi Island marine sponge screening and mapping, in Agust 2006. Specimens were deposited at the Oceanographic Research Center, Indonesian Institute of Sciences, Jakarta, Indonesia. The sponge was identified as Callyspongia aerizusa Desqueyroux-Faúndez, subgenus Callyspongia. As much as $200 \mathrm{~g}$ of the cleaned wet sponge was chopped, ground and immediately macerated with $500 \mathrm{~mL}$ of methanol three times at room temperature. The total macerate was concentrated by using a rotary evaporator. The lyophilization process yielded $15.05 \mathrm{~g}(7.525 \%)$ of sponge extract dry powder. The dry powder was stored at $-20{ }^{\circ} \mathrm{C}$ and dissolved for the phytochemical and biological activity testing purposes.

\section{Gas Chromatography-Mass Spectrometry (GC-MS) Analysis}

CA extract dry powder $(2 \mathrm{~g})$ was dissolved in $10 \mathrm{~mL}$ methanol, then $5 \mu \mathrm{L}$ injected into the Agilent Technologies 7890 Gas Chromatograph system (Santa Clara, CA, USA) and 5975 Mass Selective Detector and Chemstation Data System (Santa Clara, CA, USA). HP Ultra 2, capillary column (Agilent Technologies) and helium gas were used as the carrier gas with a flow rate of $1.2 \mu \mathrm{L} / \mathrm{min}$. The column temperature was set at $80{ }^{\circ} \mathrm{C}$ that increased $3{ }^{\circ} \mathrm{C} / \mathrm{min}$ until it reached $150{ }^{\circ} \mathrm{C}$, and then the temperature increased $20^{\circ} \mathrm{C} / \mathrm{min}$ until it reached $280^{\circ}$ $\mathrm{C}$ and was constant for $26 \mathrm{~min}$.

\section{Cell Line Culture}

The human lung carcinoma cells A549, liver hepatocellular carcinoma cells Hep G2, pancreatic carcinoma cells MIA PaCa-2, esophageal squamous cell carcinoma cell TE-8, and esophageal squamous cells Het-1A were purchased from American Type Culture Collection (Manassas, VA, USA). The A549 and TE-8 cells were cultured in Roswell Park Memorial Institute (RPMI) 1640 Medium (Gibco, Grand Island, NY, USA) supplemented with $10 \%$ fetal bovine serum (Gibco) and $1 \%$ penicillin/streptomycin (Gibco). Hep G2 cells were cultured in Eagle's Minimum Essential Medium (SigmaAldrich) supplemented with $10 \%$ fetal bovine serum. Mia Paca-2 cells were culture in Dulbecco's Modified Eagle's Medium (Sigma-Aldrich) supplemented with 10\% fetal bovine serum, $2.5 \%$ horse serum. Het-1A cells were cultured in Bronchial Epithelial Cell Growth Basal Medium kit (Lonza, Walkersville, MD, USA). 


\section{Cell Proliferation Assay}

To evaluate the anti-proliferative effect of the CA extract, the viability of the cells treated with $\mathrm{CA}$ extract was assessed for $24 \mathrm{~h}$ using Cell Counting Kit-8 (CCK-8) assay (Dojindo, Kumamoto, Japan). As much as $50 \mu \mathrm{L}$ of cells suspension (about $1 \times 10^{4}$ cells) was seeded in 96well plates (Falcon, Franklin Lakes, NJ, USA) and incubated overnight at $37{ }^{\circ} \mathrm{C}$. Fifty microliters of saline with various concentrations of $\mathrm{CA}$ extract was added to each well and incubated at $37{ }^{\circ} \mathrm{C}$ for $24 \mathrm{~h}$. To measure the viability of the cells, $10 \mu \mathrm{L}$ of the cell counting solution was added to each well and incubated at $37{ }^{\circ} \mathrm{C}$ for $3 \mathrm{~h}$. The absorbance at $450 \mathrm{~nm}$ with the reference wavelength at $620 \mathrm{~nm}$ was measured by Infinite M200 PRO microplate reader (Tecan, Männedorf, Switzerland) $3 \mathrm{~h}$ after the CCK-8 solution was given. The result was derived from triplicate experiments, and the relative cell proliferation inhibition (CPI) rate was calculated as a percentage by the following formula: CPI rate $(\%)=(1-$ absorbance of the treated cells/absorbance of the untreated cells $) \times 100$.

\section{Clonogenic Assay}

To determine the effects of the CA extract on A549 cells' colony-forming ability, the cells were prepared in a suspension by the use of trypsin (Gibco) and trypan blue (Gibco). The number of cells per milliliter was then counted using a haemocytometer. As many as 500 cells were seeded into $25 \mathrm{~cm}^{2}$ cell culture flasks with a growth medium and incubated for $24 \mathrm{~h}$. The cells were then washed out using a growth medium and treated with CA extract solution with various concentrations $(5,10,25,50$, and $100 \mu \mathrm{g} / \mathrm{mL})$. The cells were maintained in a humidified incubator at $37{ }^{\circ} \mathrm{C}$ for 2 weeks with the growth medium replacement every 2 days. Colonies were fixed and stained with Giemsa solution (Wako, Osaka, Japan). The number of colonies formed was counted using a bright-field microscope. This experiment was carried out in triplicate. Plating efficiency $=$ the number of colonies counted/number of cells plated $\times 100$. Surviving fraction $(\%)=$ plating efficiency of treated sample/plating efficiency of control $\times 100$.

\section{Propidium lodide-Hoechst 33342 Stain Apoptosis Detection}

To know the mechanism of A549 cell death upon the CA extract treatment, the A549 cells were observed every 6 h. After finding A549 cell blebs $12 \mathrm{~h}$ after being treated with CA extract, a staining experiment was carried out in order to see the phenomenon more clearly. A staining experiment was performed through dual staining of Hoechst 33342 (Dojindo) and propidium iodide (PI) (Sigma-Aldrich). The A549 cells were seeded on a cover glass and incubated for $24 \mathrm{~h}$. The cells were then treated with $10 \mu \mathrm{g} / \mathrm{mL} \mathrm{CA}$ extract and incubated for 12 and 24 $\mathrm{h}$ before being transferred to a preparatory glass. The cells were washed with non-phenol red RPMI medium (Gibco) and stained with $100 \mu \mathrm{L}$ PI and $100 \mu \mathrm{L}$ Hoechst 33342 . A549 cells were then incubated for $20 \mathrm{~min}$ at room temperature and in a dark room. A549 cells were then viewed under Apotome.2 fluorescence microscope (Zeiss, Oberkochen, Germany) with FIT-C (red) and DAPI (blue) filter. This experiment was performed in triplicate.

\section{Total RNA Isolation and Reverse Transcription-Polymerase Chain Reaction Analysis}

The A549 cell culture was treated with $10 \mu \mathrm{g} / \mathrm{mL}$ CA extract and incubated for 12 and $24 \mathrm{~h}$. The untreated A549 cell culture acted as the control group. Each treatment was performed in triplicate. The total RNA of the harvested cells was isolated from A549 cells using TRIzol ${ }^{\mathrm{TM}}$ reagent (Invitrogen, Carlsbad, CA, USA) in accordance with the standard protocols and used as a reverse transcription-polymerase chain reaction (RT-PCR) template. The purity of the RNA was determined by Infinite M200 PRO multimode microplate reader (Tecan) in A260/A280 ratio. The RNA pellet was then stored at $-20{ }^{\circ} \mathrm{C}$ until further analysis. The mRNA expression of several genes associated with apoptosis (caspase-9, caspase-3, B-cell lymphoma 2 (BCL-2), and poly (ADP-ribose) polymerase 1 (PARP-1)) and glyceraldehyde 3-phosphate dehydrogenase $(G A P D H)$, as an internal expression control, was determined using MyTaq ${ }^{\mathrm{TM}}$ One-Step RT-PCR kit (Bioline, London, UK) as per standard protocol. GAPDH was used as the reference gene.

The RT-PCR reaction was carried out using Labcycler thermal cycler (SensoQuest, Göttingen, Germany) according to the manufacturer's instructions. All primer sequences were purchased from Macrogen Inc. (Seoul, South Korea) with the specifications as shown in Table 1 in 35 cycles.

To analyze the PCR products, $4.5 \mu \mathrm{L}$ of each amplified cDNA solution was mixed with $0.5 \mu \mathrm{L}$ GelPilot $^{\mathbb{R}}$ DNA loading dye (Qiagen, Hilden, Germany) and subsequently subjected to gel electrophoresis. The gel matrix was made of $2 \%$ agarose in Tris-Acetate-EDTA buffer (Vivantis, Selangor, Malaysia) and stained with SYBR Safe Gel 
Table I Primer Sequences Specifications Used in This Study

\begin{tabular}{|c|c|c|c|}
\hline Primer & Sequenc & & $\mathrm{T}^{*}\left({ }^{\circ} \mathrm{C}\right)$ \\
\hline Caspase-9 & $\begin{array}{l}\text { Forward } \\
\text { Reverse }\end{array}$ & $\begin{array}{l}\text { 5'-AAGTGACCCTCCCAAGTAGC-3' } \\
\text { 5'-GTTCTGGCCAGGTCTCTTCT-3' }\end{array}$ & 60.5 \\
\hline Caspase-3 & $\begin{array}{l}\text { Forward } \\
\text { Reverse }\end{array}$ & $\begin{array}{l}\text { 5'-AAAATACCAGTGGAGGCCGA-3' } \\
\text { 5'-GCACAAAGCGACTGGATGAA-3' }\end{array}$ & 58.4 \\
\hline PARP-I & $\begin{array}{l}\text { Forward } \\
\text { Reverse }\end{array}$ & $\begin{array}{l}\text { 5'-TGGAACATCAAGGACGAGCT-3' } \\
\text { 5'-CATCGCTCTTGAAGACCAGC-3' }\end{array}$ & 60.5 \\
\hline BCL-2 & $\begin{array}{l}\text { Forward } \\
\text { Reverse }\end{array}$ & $\begin{array}{l}\text { 5'-TCCTCTTTACACTGGCCAGG-3' } \\
\text { 5'-GAGTATTTGTGCAGCGAGGG-3' }\end{array}$ & 60.5 \\
\hline GAPDH & $\begin{array}{l}\text { Forward } \\
\text { Reverse }\end{array}$ & $\begin{array}{l}\text { 5'-AAGGTGAAGGTCGGAGTCAAC-3' } \\
\text { 5'-CTTGATTTTGGAGGGATCTCG-3' }\end{array}$ & 57.3 \\
\hline
\end{tabular}

Note: $* \mathrm{~T}=$ annealing temperature.

Stain (Invitrogen) in order to be visualized. The mRNA expression level of several genes was quantified by an image processing program, ImageJ (NIH, Bethesda, MD, USA).

\section{Western Blot Analysis}

The A549 cells suspension was seeded in a $10 \mathrm{~cm}$ dish $\left(1 \times 10^{6}\right.$ cell $/ \mathrm{mL}$ ). The cells were then treated with CA extract with the dose of $10 \mu \mathrm{g} / \mathrm{mL}$ and incubated for 12 and $24 \mathrm{~h}$. Each treatment was performed in triplicate. The A549 cells without the CA extract treatment were used as the control. Proteins were extracted from the cells using Pro-Prep protein extraction solution. The protein concentration was determined as per standard protocol. The proteins ( $40 \mu \mathrm{g}$ per lane) were separated by $10 \%$ SDS-PAGE in Bio-Rad tank and transferred to an Amersham $^{\mathrm{TM}}$ Protran $^{\mathrm{TM}} \mathrm{NC}$ nitrocellulose membrane (GE Healthcare, Chicago, IL, USA) in Mini-PROTEAN ${ }^{\circledR}$ Tetra Cell (Bio-Rad, Hercules, CA, USA). The membrane was then washed with phosphate-buffered saline Tween-20 (PBST) $0.1 \%$, blocked with $1 \%$ skimmed milk and incubated with primary antibodies at $4{ }^{\circ} \mathrm{C}$ overnight. Before being probed with secondary antibodies, the membrane was then incubated for $1 \mathrm{~h}$ at room temperature and washed with PBST.

The protein expressions were visualized using electrochemiluminescence techniques and detected using the C-DiGit ${ }^{\circledR}$ Blot Scanner (LI-COR Biosciences, Lincoln, NE, USA). The band intensity was quantified by Image Studio Digits v. 5.2 (LI-COR Biosciences). The primary antibodies used in this study were purchased as the Apoptosis Antibody sampler kit with cat. no. 9915, containing caspase-9 (cat. no. 9508; 1:1000), caspase-3 (cat. no. 14,$220 ; 1: 1000$ ) and cleaved PARP (cat. no. 5625;
$1: 1000$ ) and Bcl-2 (cat. no. $15071 ; 1: 1000$ ) in $4{ }^{\circ} \mathrm{C}$ for $24 \mathrm{~h}$, while $\beta$-actin (cat. no. 4967; 1:5000) (Cell Signaling Technology, Danvers, MA, USA) in room temperature for $1 \mathrm{~h}$ was used as a control. The secondary antibodies used in this process were Anti-mouse IgG, HRP-linked antibody (cat. no. 7076; 1:1000; Cell Signaling Technology) and Anti-rabbit IgG, HRP-linked antibody (cat. no. 7074; 1:1000; Cell Signaling Technology).

\section{Statistical Analysis}

The quantitative data of protein expression were obtained using the band scanner Image Studio Digits v. 5.2 (LICOR Biosciences). While the quantitative data of $m R N A$ expression were calculated using ImageJ $1.52 \mathrm{v}(\mathrm{NIH}$, Bethesda, MD, USA). The measurements were assessed in triplicate, and data were presented as mean standard deviation. After calculation of the normality of the data using a stem and leaf plot, one-way ANOVA followed with Tukey's post hoc test was performed to assess the statistical significance of more than two groups. The differences were considered statistically significant when the $P$-value was $<0.05$. The statistical assessment for $m R N A$ and protein expression was performed using IBM SPSS statistic 26 (IBM Corp., NY, USA).

\section{Results}

\section{CA Extract Compound According to Gas Chromatography-Mass Spectrometry}

Compounds contained in the CA extract, according to the results of GC-MS analysis, are shown in Table 2. From the results, it was shown that most of the compounds 
Table 2 List of Compounds Contained in Callyspongia aerizusa Extract According to the Results of GC-MS Analysis

\begin{tabular}{|c|c|c|}
\hline Retention time & Compound Name & Relative Abundance (\%) \\
\hline 27.045 & Cyclododecane & 1.06 \\
\hline 27.390 & Hexadecanoic acid, methyl ester & 3.27 \\
\hline 28.672 & I I-Octadecenoic acid, methyl ester & 5.35 \\
\hline 28.824 & Octadecanoic acid, methyl ester & 3.22 \\
\hline 28.996 & $(9 \mathrm{E}, \mathrm{I2E})-9,12-$-Octadecadienoic acid & 3.77 \\
\hline 29.300 & I-Docosene & 1.04 \\
\hline 29.458 & Oleic Acid & 1.73 \\
\hline 29.851 & Methyl icosanoate & 1.25 \\
\hline 30.320 & Hexanoic acid, heptadecyl ester & 2.4 \\
\hline 30.348 & (9Z) -9 -Octadecenamide & 1.24 \\
\hline 30.451 & Arachidonic acid & 1.34 \\
\hline 30.720 & Dososanoic acid, methyl ester & 2.24 \\
\hline 30.927 & I,2 -Benzenedicarbolixylic acid dioctyl ester & 35.88 \\
\hline 30.975 & 3, I'-Dihydroxy preussomerin G & 1.02 \\
\hline 31.561 & Tetracosanoic acid, methyl ester & 1.31 \\
\hline 32.409 & 5.9-Hexacosadienoic acid, methyl ester & 2.93 \\
\hline 33.809 & Methyl 5, 9-octacosadienoate & 2.64 \\
\hline 34.175 & (22E)-Cholesta-5,22, dien-3-ol & 2.71 \\
\hline 34.526 & Cholesterol & 2.64 \\
\hline 34.995 & Ergost-22-en-3-one, $(5 ß, 22 \mathrm{E})$ & 7.11 \\
\hline 35.643 & Ergost-7-en-3-ol,,(35ß) & 5.33 \\
\hline 36.002 & Stigmasterol & 1.5 \\
\hline 36.767 & B-Sitosterol & 1.72 \\
\hline
\end{tabular}

contained in the extract were fatty acids and steroids. The distinctive compounds found in these CA sponges were ergost-22-en-3-one $(5 \beta, 22 E ; m / z \quad 398.4 ; 7.11 \%)$ and ergost-7-en-3-ol $(35 \beta ; \mathrm{m} / \mathrm{z} 400.4 ; 5.33 \%)$ that was predicted as the active components. The graph of the GCMS analysis result of CA extract compounds is presented in Figure 1. Since the efficacy of any ergosteroids from CA has not been previously reported to any cancer cells, we then conducted a screening test on several cancerous cell lines and selected A549 cells in advance.

\section{Cell Viability Inhibition by CA Extract in Several Cells}

CA extract was observed to inhibit the proliferation of some cancerous cells in a dose-dependent manner. Table 3 shows the $\mathrm{IC}_{50}$ value of $\mathrm{CA}$ extract against four cancerous human cell lines (A549, Hep G2, MIA PaCa-2, and TE-8) and a noncancerous human cell line, Het-1A, after $24 \mathrm{~h}$ treatment. It was found that $\mathrm{CA}$ extract demonstrated cytotoxicity toward all of the cancerous cells. The A549 cells ( $\left.\mathrm{IC}_{50} 9.38 \mu \mathrm{g} / \mathrm{mL}\right)$ were shown to be more susceptible than the Hep $\mathrm{G} 2\left(\mathrm{IC}_{50} 10.62 \mu \mathrm{g} /\right.$ $\mathrm{mL})$ and the MIA PaCa-2 ( $\left.\mathrm{IC}_{50} 10.72 \mu \mathrm{g} / \mathrm{mL}\right)$, however, the TE-8 cells ( $\left.\mathrm{IC}_{50} 3.12 \mu \mathrm{g} / \mathrm{mL}\right)$ are three times more susceptible than the A549 cells. Since A549 cells represented the most prevalent type of lung cancer, this study then conducted several tests focused on these cells. In contrast with the cancerous cell line subjects, cytotoxicity was not seen in the non-cancerous Het-1A cells, even after extract administration up to $1000 \mu \mathrm{g} /$ $\mathrm{mL}$. The result suggests that the CA extract does not act as a cytotoxic to non-cancerous cells.

\section{Colony Formation Inhibition by CA Extract in A549 Cells}

Colony formation inhibition assay had shown the effect of CA extract not only enhanced cell death but also attenuated the survival of A549 cells by reducing the colony-forming ability of the cells in a dose-dependent manner. Inhibition of A549 cells colony formation by the CA extract was plotted as cell survival rate curve in Figure 2.

\section{A549 Cells Observation}

Observation of A549 cells morphology after CA extract treatment showed significant alterations compared to the untreated one that is shown in Figure 3. The untreated cells (Figure 3A) appeared to have an oval shape. This $0 \mathrm{~h}$ imaging portrayed the living cells with the normal structural form before the process of apoptosis. In contrast, after $12 \mathrm{~h}$ treatment (Figure 3B), the cells treated 

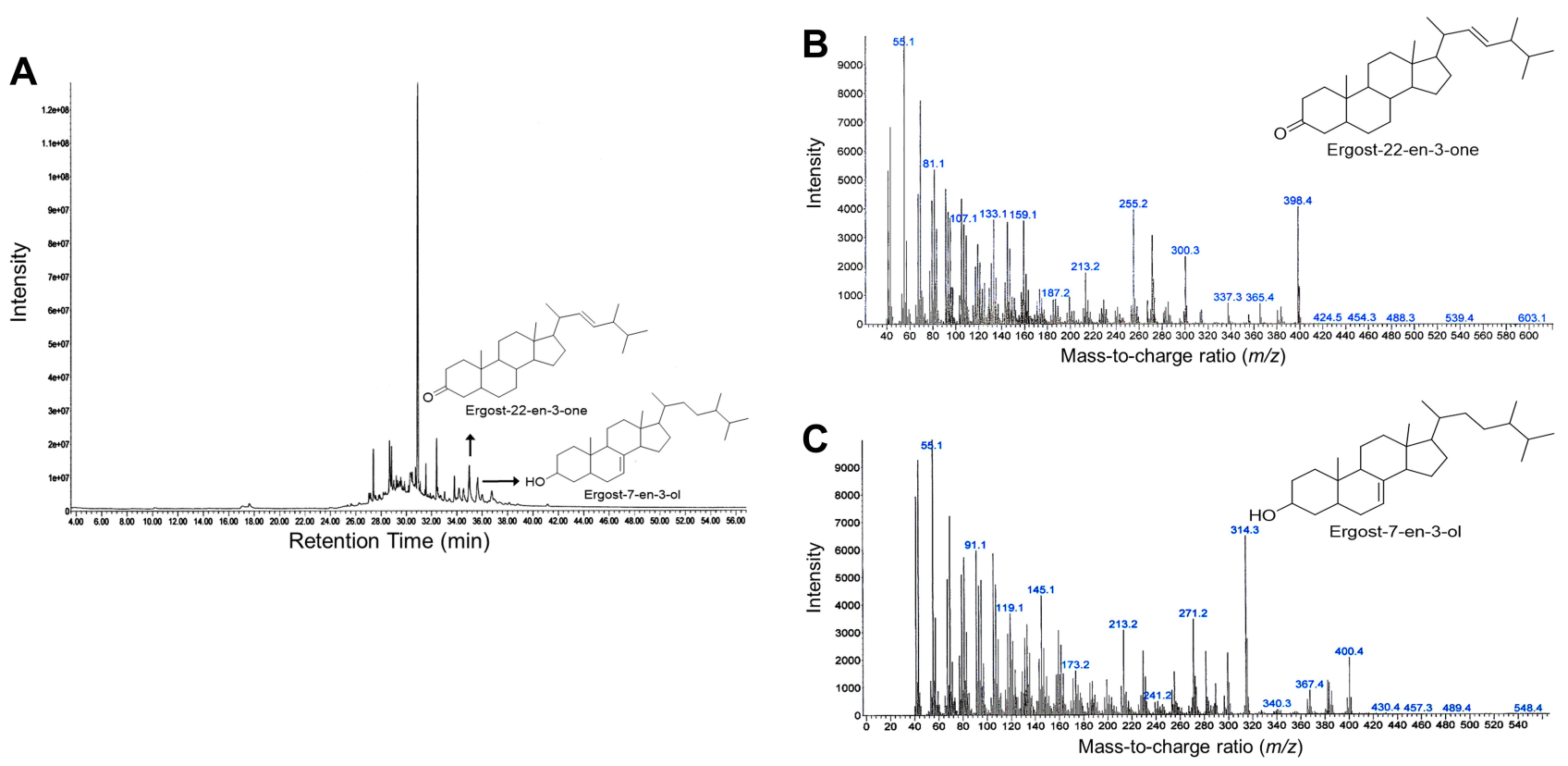

Figure I Graph of gas chromatography-mass spectrometry (GC-MS) chromatogram of CA sponges extract. (A) GC-MS chromatogram that represents overall peaks of CA sponges extract compound, $x$-axis represents retention time in minutes and $y$-axis represent intensity. The peaks that are designated by an arrow are peaks of ergost-22-en -3-one and ergost-7-en-3-ol. (B) GC-MS chromatogram of ergost-22-en-3-one and (C) ergost-7-en-3-ol mass weight ( $\mathrm{m} / \mathrm{z})$. The chemical structure of compounds that are shown are reproduced from Chem Draw software version 16.0.I.h (77) (Santa Clara, CA, USA).

with CA extract had exhibited the typical features of apoptotic cells: the cells appeared to shrink, the condensed chromatin, and fragmented nuclear. These cells also started to lose their plasma membrane integrity but still maintained their cellular form. This result suggested that the A549 cells were still in the process of apoptosis. On the $24 \mathrm{~h}$ observation (Figure 3C), there was not a form of cell that could be detected, perhaps due to all A549 cells having gone completely through the apoptosis process, where the cells had broken into apoptotic bodies containing the organelles and destroyed nucleus. Based on these observations, the apoptosis of A549 cells induced by the CA extract occurred between 12 and $24 \mathrm{~h}$.

Table $3 \mathrm{IC}_{50}$ of CA Methanol Extract Against Several Cell Lines

\begin{tabular}{|l|l|}
\hline Cell Lines & IC $_{\mathbf{5 0}}(\boldsymbol{\mu g} / \mathbf{m L})$ \\
\hline A549 & 9.38 \\
HEP G2 & 10.62 \\
MIA PaCa-2 & 10.72 \\
TE-8 & 3.12 \\
Het-IA & n.d.* \\
\hline
\end{tabular}

Note: ${ }^{*}$.d. $=$ not determined.

\section{The mRNA Expressions in A549 Cells Induced by CA Extract}

The $m R N A$ expressions of several genes in A549 cells after the CA extract treatment were observed by RTPCR. The electrophoresis gel visualization detected the

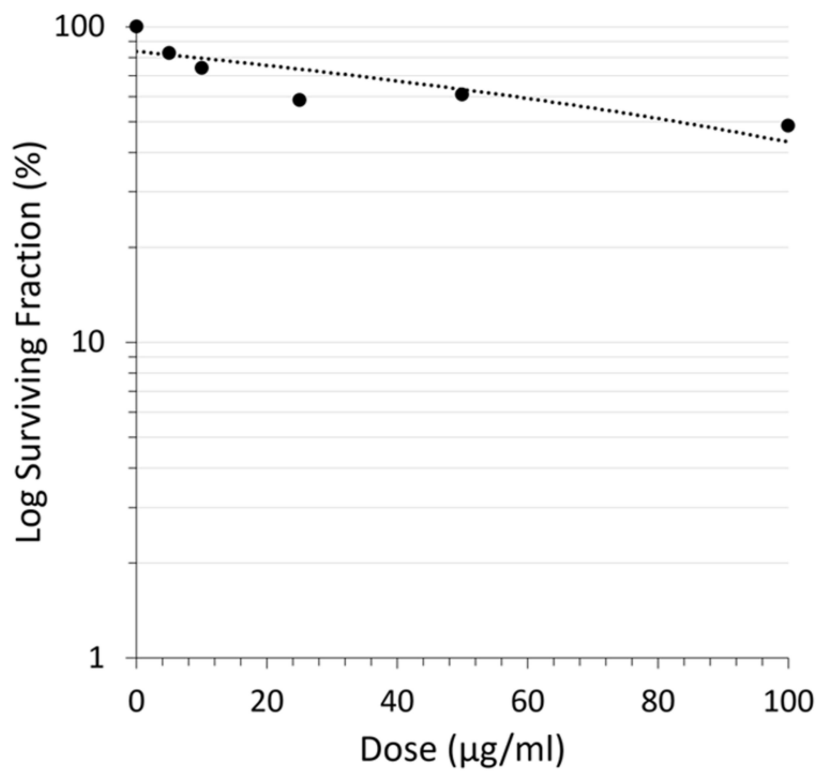

Figure 2 Reduction of A549 cells' colony-forming ability after CA sponges extract treatment. The cell's survival rate curve plots the dose of CA sponges extract and surviving fraction of retaining A549 cells. 
A

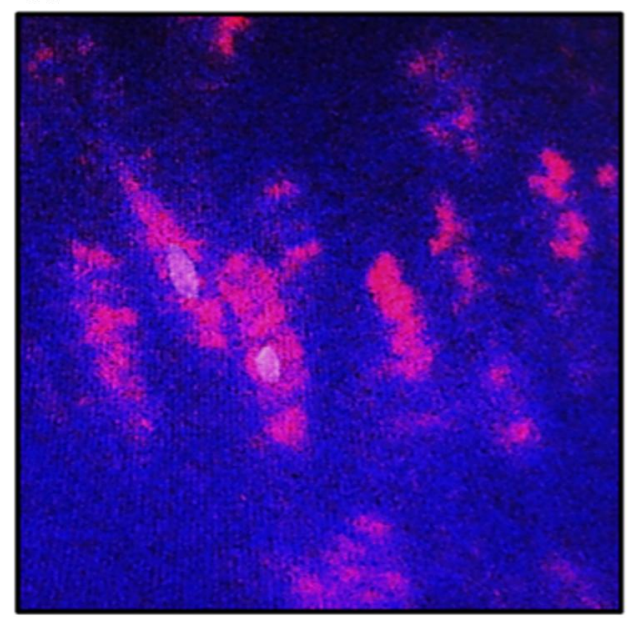

C

\section{B}

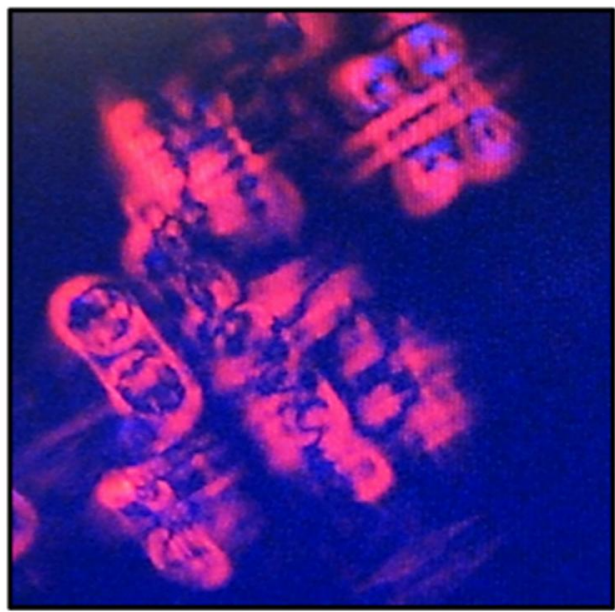

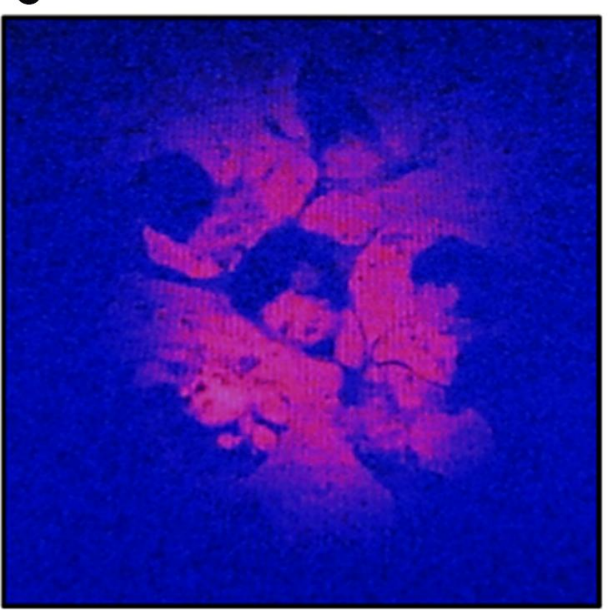

Figure 3 Morphological changes of A549 cells after treatment with CA sponges extract, detected by dual staining of Hoechst 33342 and propidium iodide (PI). (A) The untreated cells or $0 \mathrm{~h}$ observation, indicated structurally normal viable cells with normal nuclei. (B) After $12 \mathrm{~h}$ of CA sponges extract treatment, A549 cells were expected to be apoptotic as evidenced by the cell shrinkage and the separation of condensed chromatin. (C) On 24 h observation, the plasma membrane of A549 cells had lost their integrity and formed apoptotic bodies.

expression of apoptosis-related genes (caspase-9, caspase3, PARP-1, BCL-2) and GAPDH, as the internal control (Figure 4A). After the $12 \mathrm{~h}$ treatment of CA extract, the expression of caspase- 9 appeared to have increased (44.1\%) compared to the expression in $0 \mathrm{~h}$, as seen at 190 bp. A significant, similar gene-expression alteration was also shown in caspase-3 (49.7\%) at $107 \mathrm{bp}(P=$ 0.009 ) according to one-way ANOVA analysis. Despite its significance $(P=0.031), P A R P-1$ expression was also found to slightly increase $(25.2 \%)$, as seen at $187 \mathrm{bp}$. In contrast, at the same time, the expression $B C L-2$ appeared to have a significant decrease $(5.7 \%)(P<0.0001)$, as seen at $145 \mathrm{bp}$ (Figure 4B). The escalation of caspase-9, caspase-3 and PARP-1 expression and the decline of BCL-2 induced by the $\mathrm{CA}$ extract showed the involvement of the caspase-cascade in the apoptotic process induced by the CA extract. After $24 \mathrm{~h}$, the $m R N A$ expression of all genes had declined; this result might be due to the end process of apoptosis at the time.

\section{The Protein Expressions in A549 Cells Induced by CA Extract}

Since the apoptotic cell death of A549 cells seemed to be induced, based on the cell's morphological appearance and $m R N A$ levels, in order to confirm the responsible proteins were synthesized and activated, Western blot analyses were carried out after the CA extract treatment. As shown in Figure $5 \mathrm{~A}$, the expression level of some pro-apoptotic proteins, caspase-9 and caspase-3, and PARP-1 in A549 cells at $12 \mathrm{~h}$ were detected to escalate, compared to the untreated ones. The 
A

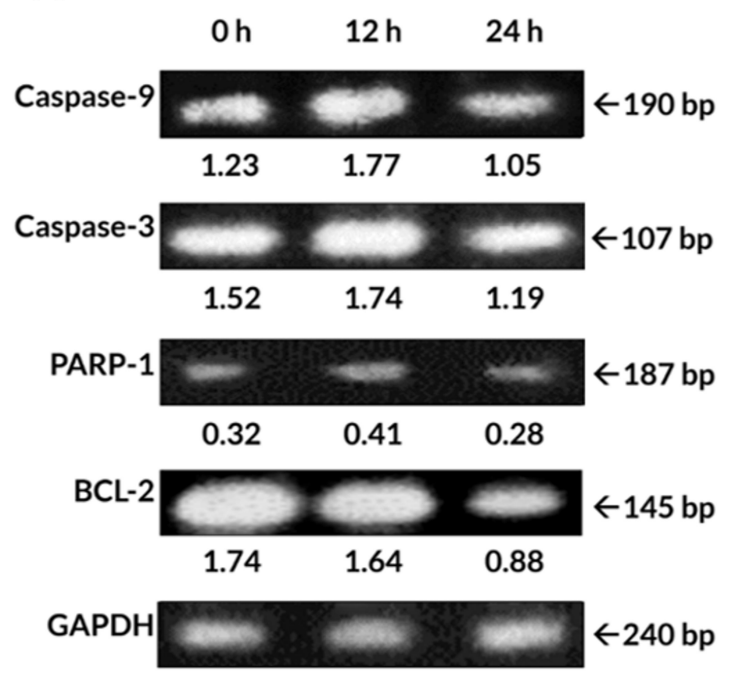

B

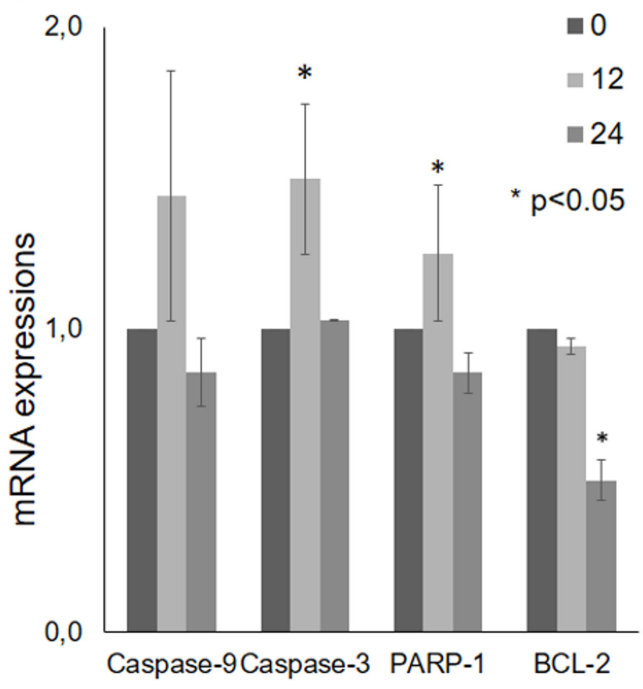

Observation time $(\mathrm{h})$

Figure 4 The $m R N A$ expression detection using reverse transcription-polymerase chain reaction (RT-PCR). (A) CA sponges extract treatment in A549 cells not only lead to the up-regulation of caspase-9, caspase-3 and PARP-I but also the down-regulation of the BCL-2 that shown in band, and (B) bar graph. Quantitative data of band density measured using image $1.52 \mathrm{v}(\mathrm{NIH})$. Data are presented as mean \pm standard deviation. One-way ANOVA followed by Tukey's post hoc test was performed. *P <0.05.

A

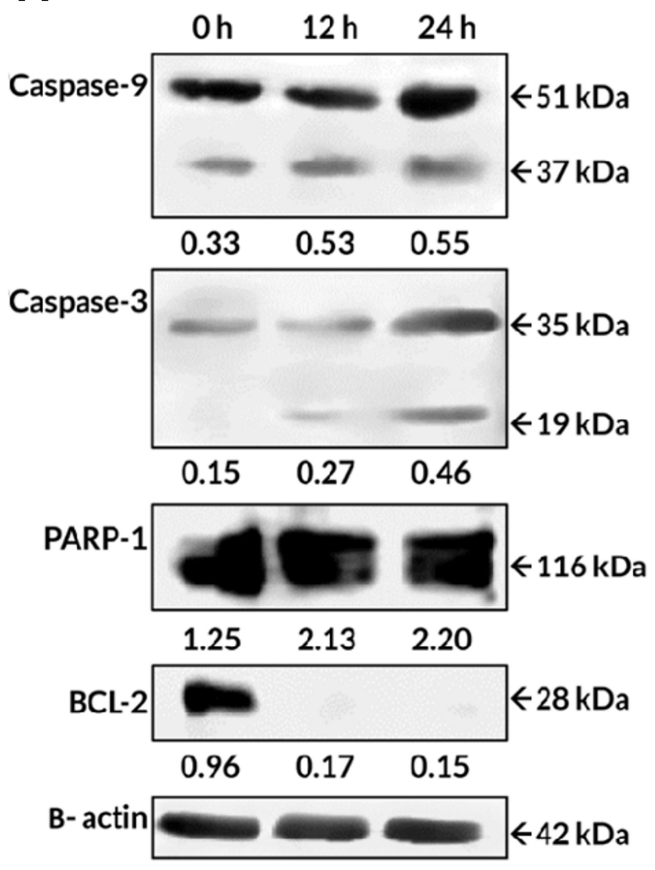

B

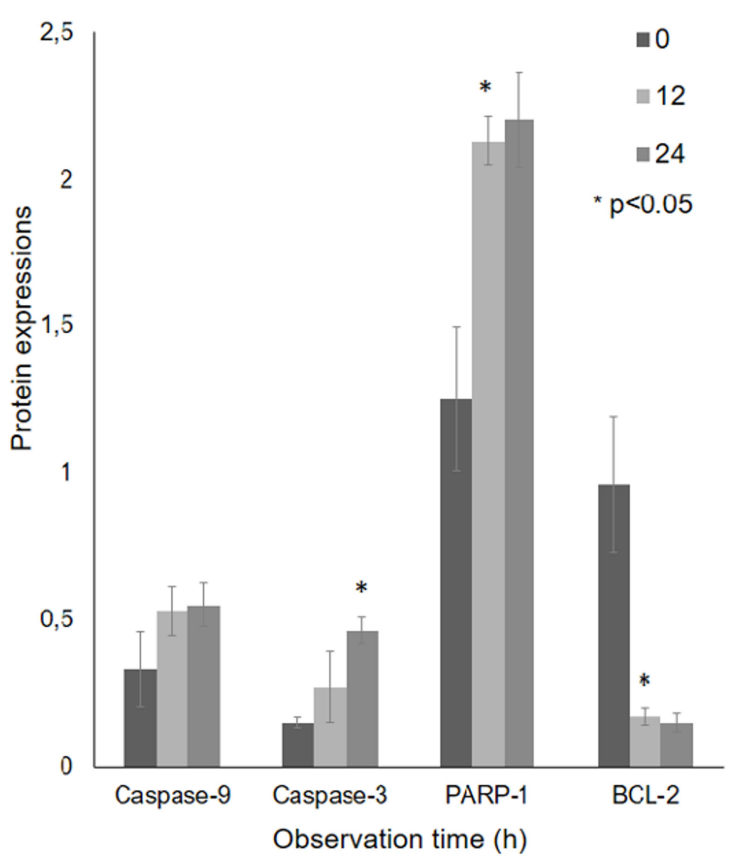

Figure 5 Protein expressions of the caspase-9, caspase-3, PARP-I, BCL-2 obtained by Western blotting in A549 cells treated with CA extract. (A) CA extract induced apoptotic cell death through activation of caspase-9 then triggered caspase-3. Moreover, BCL-2 antiapoptotic protein in A549 cells was suppressed after being treated with CA extract, shown in band and (B) bar graph. Quantitative data of band density measured using Image Studio Digits v. 5.2 (LI-COR Biosciences). One-way ANOVA followed with Tukey's post hoc test was performed. *P $<0.05$.

cleavage of caspase-9 (37 kDa) expression appeared to have slightly increased at $12 \mathrm{~h}(61.1 \%)$ and $24 \mathrm{~h}(67.8 \%)$ compared to $0 \mathrm{~h}$, indicating that this initiator caspase was activated after the CA extract treatment. The expression caspase-3 cleavage (19 kDa) appeared from $12 \mathrm{~h}(78.4 \%)$ and was found to significantly increase $(P=0.006)$ at $24 \mathrm{~h}(205.6 \%)$. This result 
demonstrated caspase-3, as the executor caspase, was activated after the induction of the activated caspase-9. The PARP-1 $(116 \mathrm{kDa})$ expression was significantly increased $(P=0.001)$ at $12 \mathrm{~h}(69.8 \%)$ and $24 \mathrm{~h}(75.1 \%)$ observation. In contrast, BCL-2 expression seemed to be significantly suppressed $(P=$ 0.01 ) after the $\mathrm{CA}$ treatment at 12 and $24 \mathrm{~h}$ compared to 0 $\mathrm{h}$ (Figure 5B). These results indicate that BCL-2 expression, as an anti-apoptotic factor, was detected to be suppressed in order to confirm that the apoptotic process occurred in A549 cells. According to these results, the CA extracts were proven to be able to induce apoptosis through the up-regulation of caspase9, caspase-3 and PARP-1, and also down-regulation of BCL-2.

\section{Discussion}

Current treatments for lung cancer have not yet obtained satisfactory results, as evidenced by the prognosis for this disease of less than $18 \%$, which is the worst survival outcome among cancer diseases. ${ }^{16}$ The fact that lung cancer has still become the leading cause of cancer-related deaths (19.4\%) worldwide has set the high urgency to find a better therapeutic agent for this disease. Recently, the series of cyclic peptides isolated from CA, the Callyaerins, had been reported to possess several biological activities, such as antibacterial, antifungal, and anticancer. ${ }^{15}$ However, in the present study, we found some ergosteroids compounds, ergost-22-en-3-one $(5 \beta, 22 E)$ and ergost-7-en-3-ol (35 $\beta$ ) derived from the CA that also exhibited anti-proliferation effects on several cancerous cell lines $\left(\mathrm{IC}_{50} 3.12-10.72 \mu \mathrm{g} / \mathrm{mL}\right.$ ). We also found that CA extract exhibited colony formation suppression towards human lung carcinoma cells A549 and induced apoptosis as its mechanism of cell death. The cell death mechanism was further confirmed by the up-regulation of caspase-9, caspase-3, PARP-1, and the down-regulation of BCL-2 expression in both $m R N A$ and protein levels.

To investigate the metabolites presented in the extract, we carried out a GC-MS analysis. The present phytochemical result revealed that crude methanol extract of CA contained ergosteroids (Table 2 and Figure 1). Ergost-22-en-3-one $(5 \beta, 22 E)$ and ergost-7-en-3-ol (35 $\beta)$ are included in ergosteroids, which in some previous studies found on Aspergillus which is symbiotic with certain sponges. ${ }^{17,18}$ The previous in vitro studies have shown that constituents from CA extract possessed several biological activities, including cytotoxicity. ${ }^{15}$ Some of the reported mechanisms possessed by steroids enable them to act as anticancer agents by inhibiting Wnt/ß-catenin signaling in colon cancer, ${ }^{19}$ inhibiting PSA expression, and glucose uptake. ${ }^{20}$
The proliferation assay data in the present study indicated that CA extract significantly inhibited the proliferation of human lung carcinoma cells A549 after $24 \mathrm{~h}$ treatment. The $\mathrm{IC}_{50}$ of the CA extract was calculated to be $9.38 \mu \mathrm{g} / \mathrm{mL}$, which is categorized as a strong cytotoxic $(<10 \mu \mathrm{g} / \mathrm{mL}){ }^{21}$ To date, no other study has reported cytotoxicity levels of CA extract towards the A549 cells, except for Callyaerins E and H, the active cyclic peptide isolates derived from CA. These compounds exhibited strong anti-proliferation in the L5178Y cell lines with $\mathrm{IC}_{50}$ values of 0.50 and $0.51 \mu \mathrm{g} / \mathrm{mL},{ }^{15}$ however, the stronger results in this previous study may have occurred due to different cells having different susceptibilities. Another factor that may have affected the previous study result was the use of pure isolates, while in the present study, we just examined the activity of crude methanol extract. Compared to the noncancerous cell model of the present study using Het-1A cells, cytotoxicity was not seen even after the maximum administration. Similar results were also found in a previous study, which revealed that metabolites in $\mathrm{CA}$ exhibited no cytotoxicity against normal lung fibroblast cells (MRC-5). ${ }^{22}$ The other three cancerous cells lines in the present study that were susceptible to CA extract also suggested that the extract was able to selectively inhibit the proliferation of cancerous cells and was found to be less toxic in non-cancerous cells.

The colony formation ability of A549 cells induced by various concentrations of CA extract was further evaluated after 14 days of incubation. As shown in Figure 2, the higher concentration of CA extracted a lower plating efficiency of A549 cells, as evidenced by the decreasing number of colonies formed. This finding indicated that $\mathrm{CA}$ extract decreases the clonogenic property of individual cells of A549, synergistically as a result of cell proliferation assay. Compared to the previous A549 cells' clonogenic assays using a methanol extract of Haliclona sp., this result showed lower colony suppressing ability at a dose of $100 \mu \mathrm{g} / \mathrm{mL}^{23}$ but interestingly, the CA extract showed better performance for this assay at lower concentrations. It might be possible that the A549 cells are more sensitive toward CA extract compared to the extract of Haliclona sp. A recent morphological study further confirmed apoptosis as the underlying mechanism of cell death elicited by the CA extract in A549 cancer cells. After $12 \mathrm{~h}$ treatment of CA extract, the A549 cells showed the typical features of cells undergoing apoptosis, and the cells appeared to shrink compared to the control; the chromatin had condensed and the nucleus had fragmented, shown as blue fluorescence due to the Hoechst 33342 dye and the apoptotic bodies that had started to form. After $12 \mathrm{~h}$ observation, the cells also started to lose their plasma membrane integrity, as evidenced by red 
fluorescence from the PI dye. These results are similar to the previous morphological study of apoptosis in A549 cells, where under electron microscopy the A549 cells that were undergoing apoptosis had some distinctive characteristics, including cell shrinkage, chromatin aggregation, membrane blebbing, and the appearance of apoptotic bodies. ${ }^{24}$ The same result was also obtained in a previous morphological apoptosis study of A549 cells treated with curcumin. ${ }^{25}$ Either CA extract or curcumin had induced apoptosis within $24 \mathrm{~h}$. The fact that this extract could induce apoptosis to A549 cells is highly desirable, since $50 \%$ of lung cancer types are associated with p53 mutation, which causes failure of apoptosis activation. ${ }^{26,27}$ As the CA extract might induce apoptosis, this agent can eliminate malignant cells without damaging normal cells and surrounding tissues. ${ }^{28}$

The apoptotic molecular mechanism induced by CA extract was investigated by assessing the alteration of apoptosis-related molecules in $m R N A$ expression level. In the RTPCR results, during the $12 \mathrm{~h}$ observation, induction of apoptosis in A549 cells was accompanied by the up-regulation of proapoptotic molecules (caspase-9, and caspase-3) and the downregulation of one of the anti-apoptotic molecules, BCL-2. Caspase-9, as the initiator, is known to play a critical role in the apoptosis signal transduction process. ${ }^{29}$ The up-regulation of caspase-9 was reported to trigger its self-activation and consequently cause the activation of another member of the caspase family, the executor caspases. ${ }^{30,31}$ Caspase- 3 , as the main executor caspase, was involved in the division of other proteolysis proteins, which in this study was PARP-1, which was considered as a typical feature of apoptosis. ${ }^{32,33}$ These findings suggested that apoptosis occurred through the intrinsic pathways as a result of CA extract treatment. In the 24 h observation, the expression of caspase-9, caspase-3, PARP1 , and $B C L-2$ were decreased (Figure 4A); this might happen due to the end process of apoptosis that was proven by the unstable form of cells in a recent morphological study. ${ }^{24}$ Previous studies have identified that before the end process of apoptosis, caspase-3 activates the other executor proteins, such as caspase-activated DNase, ${ }^{34}$ an endonuclease that degrades DNA and terminates the process of gene expression. Apoptosis, as the mechanism of death, also occurred in this study, supported by the suppressed expression of BCL-2. In response to types of cell stress or damage, BCL-associated $\mathrm{X}$ proteins will be released from the bond with BCL-2 and create pores in the mitochondrial outer membrane, a condition that leads to the release of cytochrome $\mathrm{C}$ and further caspase pathway activation. ${ }^{35}$

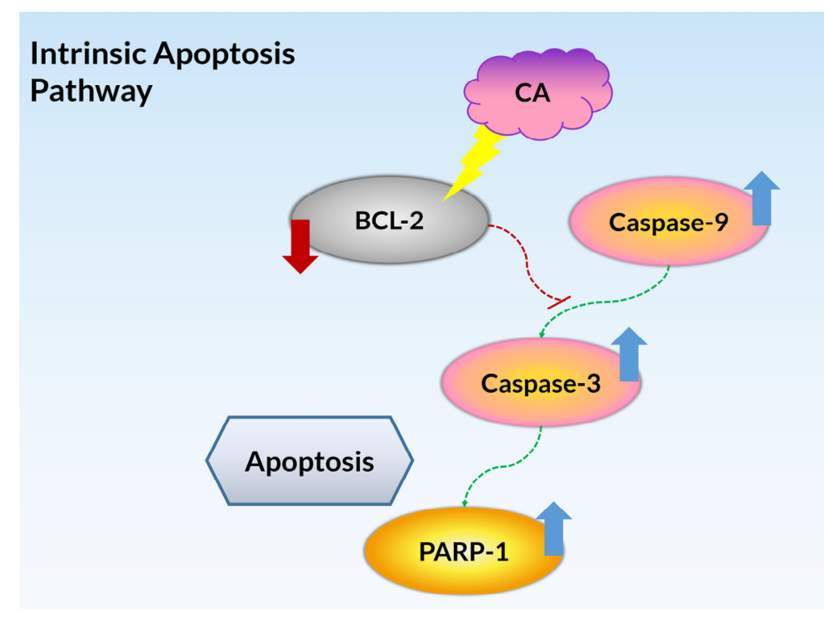

Figure 6 The summarized pathway mechanisms for CA-induced apoptosis in A549 cells.

The Western blot analysis confirmed the occurrence of the caspase cascade as the apoptosis pathway induced by the treatment of CA extract in A549 cells, which involved caspase-9, caspase-3, PARP-1, and BCL-2 proteins. All of the synthesized proteins have a similar expression pattern with the genes encoding those proteins, indicating all of the genes were expressed and translated into proteins. After the $12 \mathrm{~h}$ treatment, the caspase- 9 and caspase- 3 were activated, as evidenced by the presence of their cleavage (Figure 5A). The increased expression of caspase- 9 and caspase-3 cleavages indicated the intrinsic pathway as the underlying mechanism of apoptosis. Moreover, this result was also supported by the detection of protein expression of caspase-7 (data not shown), a protein related to the extrinsic pathway, did which not show any increase after the CA treatment. Despite PARP-1 also increasing its expression, its cleavages were not seen either in 12 or 24 $\mathrm{h}$, suggesting the fragment had not been formed at the time. Meanwhile, the expression of BCL-2 was suppressed after the 12 and $24 \mathrm{~h}$, suggesting the downstream of the apoptosis signaling process was activated after the CA extract treatment. Overall, the present comprehensive bioactive studies of CA extract on human lung carcinoma cells A549 are summarized in Figure 6.

Since it was proven that CA possesses the ability to induce the internal pathway of apoptotic cell death via caspase cascade in A549 cells, as a continuation of this research, we are going to characterize other potential properties of this crude methanol extract. To date, the different biological tests and exploration of malignancy pathway by CA extract are ongoing research. Meanwhile, for future research, a scale-up of CA extract production and in vivo experiments is being planned. 


\section{Conclusions}

In conclusion, two ergosteroids derived from the marine sponge Callyspongia aerizusa possess strong cytotoxic and colony inhibition ability in human lung carcinoma cells A549. The combination of properties, including the up-regulation of proapoptotic molecules and inhibition of anti-apoptotic molecules related to the caspase cascade-dependent signaling pathway, shows these compounds to be promising candidates for future anticancer therapy.

\section{Abbreviations}

CA, Callyspongia aerizusa; GC-MS, gas chromatographymass spectrometry; CCK-8, cell counting Kit-8; CPI, cell proliferation inhibition; $\mathrm{IC}_{50}$, half-maximal inhibitory concentration; PI, propidium iodide; RT-PCR, reverse transcription-polymerase chain reaction; BCL-2, B-cell lymphoma 2; PARP-1, Poly (ADP-ribose) polymerase 1; GAPDH, glyceraldehyde 3-phosphate dehydrogenase; PBST, phosphate-buffered saline Tween-20.

\section{Acknowledgments}

The authors would like to thank Professor Unang Supratman (Laboratorium Central, Universitas Padjadjaran West Java; Indonesia), for providing all the necessary facilities to carry out the present work. The authors would also like to thank Ms. Susianti and Ms. Kusmiati Sukmana for their excellent technical support and assistance. This research was funded by Universitas Padjadjaran Internal Grant 2017-2018, grant number 7511/UN6.O/PL/2018.

\section{Disclosure}

All authors report no conflicts of interest in this work.

\section{References}

1. Weinstein IB, Case K. The history of cancer research: introducing an AACR centennial series. Cancer Res. 2008;68(17):6861-6862. doi:10.1158/0008-5472.CAN-08-2827

2. Ferlay J, Soerjomataram I, Dikshit R, et al. Cancer incidence and mortality worldwide: sources, methods and major patterns in GLOBOCAN 2012. Int $J$ Cancer. 2015;136(5):359-386. doi:10.1002/ijc. 29210

3. Steward BW, Wild CP. World Cancer Report 2014. Lyon, France: IARC; 2014:54-67.

4. Mansoori B, Mohammadi K, Davudian S, Shirjang S, Baradaran B. The different mechanisms of cancer drug resistance: a brief review. Adv Pharm Bull. 2017;7(3):339-348. doi:10.15171/apb.2017.041

5. Malve H. Exploring the Ocean for new drug developments: marine pharmacology. J Pharm Bioallied Sci. 2016;8(2):83-91. doi:10.4103/ 0975-7406.171700
6. Abdelmohsen UR, Balasubramanian S, Oelschlaeger TA, et al. Potential of marine natural products against drug-resistant fungal, viral, and parasitic infections. Lancet Infect Dis. 2017;17(2):30-41. doi:10.1016/S1473-3099(16)30323-1

7. Hu Y, Chen J, Hu G, et al. Statistical research on the bioactivity of new marine natural products discovered during the 28 years from 1985 to 2012. Mar Drugs. 2015;13(1):202-221. doi:10.3390/md13010202

8. Aiub C, Giannerini A, Ferreira F, et al. Genotoxic evaluation of extracts from Aplysina fulva, A Brazilian marine sponge. Mutat Res. 2006;611(1-2):34-41. doi:10.1016/j.mrgentox.2006.06.035

9. De Flora S, Bagnasco M, Bennicelli C, Camoirano A, Bojnemirski A, Kurelec B. Biotransformation of genotoxic agents in marine sponges: mechanisms and modulation. Mutagenesis. 1995;10(4):357-364. doi:10.1093/mutage/10.4.357

10. Rady HM, Hassan AZ, Salem SM, et al. Induction of apoptosis and cell cycle arrest by Negombata magnifica sponge in hepatocellular carcinoma. Med Chem Res. 2016;25(3):456-465. doi:10.1007/ s00044-015-1491-9

11. Mioso R, Marante FJT, Bezerra RS, Borges FVP, Santos BVO, de Laguna IHB. Cytotoxic compounds derived from marine sponges. a review (2010-2012). Molecules. 2017;22(2):208. doi:10.3390/ molecules 22020208

12. Costantini S, Romano G, Rusolo F, et al. Anti-inflammatory effects of a methanol extract from the marine sponge Geodia cydonium on the human breast cancer MCF-7 cell line. Mediators Inflamm. 2015;2015:204975. doi:10.1155/2015/204975

13. Choi C, Son A, Lee HS, Lee YJ, Park HC. Radiosensitization by marine sponge Agelas sp. extracts in hepatocellular carcinoma cells with autophagy induction. Sci Rep. 2018;8(1):6317. doi:10.1038/ s41598-018-24745-w

14. Desqueyroux-Faúndez R. Description de la faune des haplosclerida (Porifera) de la Nouvelle-Calédonie.I. Niphatidae-Callyspongiidae. Rev Suisse Zool. 1984;91:765-827. doi:10.5962/bhl.part.81580

15. Ibrahim SRM, Min CC, Teuscher F, et al. Callyaerins A-F and H, new cytotoxic cyclic peptides from the indonesian marine sponge Callyspongia aerizusa. Bioorg Med Chem. 2010;18(14):4947-4956. doi:10.1016/j.bmc.2010.06.012

16. Siegel RL, Miller KD, Jemal A. Cancer statistics, 2018. CA Cancer J Clin. 2018;68(1):7-30. doi:10.3322/caac.21442

17. Cui CM, Li XM, Li M, Li CS, Huang CG, Wang BG. 7-norergosterolide, a pentalactone-containing norsteroid and related steroids from the marine-derived endophytic aspergillus ochraceus EN-31. J Nat Prod. 2010;73(11):1780-1784. doi:10.1021/ np100386q

18. Gu BB, Wu W, Jiao FR, et al. Asperflotone, an $8(14 \rightarrow 15)$-abeo-ergostane from the sponge-derived fungus aspergillus flocculosus 16D-1. J Org Chem. 2019;84(1):300-306. doi:10.1021/acs.joc.8b02679

19. Park HB, Tuan NQ, Oh J, et al. Sesterterpenoid and steroid metabolites from a deep-water alaska sponge inhibit Wnt/ $\beta$-catenin signaling in colon cancer cells. Mar Drugs. 2018;16(9):297. doi:10.3390/md16090297

20. Tabakmakher KM, Makarieva TN, Denisenko VA, et al. New trisulfated steroids from the vietnamese marine sponge halichondria vansoesti and their PSA expression and glucose uptake inhibitory activities. Mar Drugs. 2019;17(8):445. doi:10.3390/md17080445

21. Caamal-Fuentes EE, Peraza-Sánchez SR, Torres-Tapia LW, Moo-Puc RE. Isolation and identification of cytotoxic compounds from Aeschynomene fascicularis, A mayan medicinal plant. Molecules. 2015;20(8):13563-13574. doi:10.3390/molecules200813563

22. Daletos G, Kalscheuer R, Koliwer-Brandl H, et al. Callyaerins from the marine sponge Callyspongia aerizusa: cyclic peptides with antitubercular activity. J Nat Prod. 2015;78(8):1910-1925. doi:10.1021/ acs.jnatprod.5b00266

23. Bae W, Lim HK, Kim KM, et al. Apoptosis-inducing activity of marine sponge haliclona sp. extracts collected from kosrae in nonsmall cell lung cancer A549 cells. Evid Based Complement Alternat Med. 2015;2015:1-8. doi:10.1155/2015/717959 
24. Moongkarndi P, Kosem N, Kaslungka S, Luanratana O, Pongpan N, Neungton N. Antiproliferation, antioxidation and induction of apoptosis by Garcinia mangostana (mangosteen) on SKBR3 human breast cancer cell line. J Ethnopharmacol. 2004;90(1):161-166. doi:10.1016/j. jep.2003.09.048

25. Yao Q, Lin M, Wang Y, et al. Curcumin induces the apoptosis of A549 cells via oxidative stress and MAPK signaling pathways. Int $\mathrm{J} \mathrm{Mol}$ Med. 2015;36(4):1118-1126. doi:10.3892/ijmm.2015.2327

26. Rodin SN, Rodin AS. Origins and selection of p53 mutations in lung carcinogenesis. Semin Cancer Biol. 2005;15(2):103-112. doi:10.1016/ j.semcancer.2004.08.005

27. Pore MM, Hiltermann TJN, Kruyt FAE. Targeting apoptosis pathways in lung cancer. Cancer Lett. 2013;332(2):359-368. doi:10.1016/ j.canlet.2010.09.012

28. Ashkenazi A. Directing cancer cells to self-destruct with pro-apoptotic receptor agonists. Nat Rev Drug Discov. 2008;7 (12):1001-1012. doi:10.1038/nrd2637

29. Würstle ML, Laussmann MA, Rehm M. The central role of initiator caspase- 9 in apoptosis signal transduction and the regulation of its activation and activity on the apoptosome. Exp Cell Res. 2012;318 (11):1213-1220. doi:10.1016/j.yexcr.2012.02.013
30. Druškovič M, Šuput D, Milisav I. Overexpression of caspase-9 triggers its activation and apoptosis in vitro. Croat Med J. 2006;47 (6):832-840.

31. Thornberry NA, Lazebnik Y. Caspases: enemies Within. Science. 1998;281(5381):1312-1316. doi:10.1126/science.281.5381.1312

32. Fernandes-Alnemri T, Litwack G, Alnemri ES. CPP32, a novel human apoptotic protein with homology to Caenorhabditis elegans cell death protein Ced-3 and mammalian interleukin-1 beta-converting enzyme. J Biol Chem. 1994;269(49):30761-30764. doi:10.1016/S0021-9258(18)47344-9

33. Kaufmann SH, Desnoyers S, Ottaviano Y, Davidson NE, Poirier GG. Specific proteolytic cleavage of poly (ADP-ribose) polymerase: an early marker of chemotherapy-induced apoptosis. Cancer Res. 1993;53(17):3976-3985.

34. Widlak P. the dff40/cad endonuclease and its role in apoptosis. Acta Biochim Pol. 2000;47(4):1037-1044. doi:10.18388/abp.2000_3957

35. Brunelle JK, Letai A. Control of mitochondrial apoptosis by the Bcl-2 family. J Cell Sci. 2009;122(4):437-441. doi:10.1242/jcs.031682

\section{Publish your work in this journal}

Drug Design, Development and Therapy is an international, peerreviewed open-access journal that spans the spectrum of drug design and development through to clinical applications. Clinical outcomes, patient safety, and programs for the development and effective, safe, and sustained use of medicines are a feature of the journal, which has also been accepted for indexing on PubMed Central. The manuscript management system is completely online and includes a very quick and fair peer-review system, which is all easy to use. Visit http://www. dovepress.com/testimonials.php to read real quotes from published authors. 